\title{
Development of integration processes in the agricultural sector
}

\author{
Farit Mukhametgaliev ${ }^{1 *}$, Landysh Sitdikova $^{1}$, Farida $_{\text {Mukhametgalieva }}{ }^{1}$, and Alina Battalova ${ }^{2}$ \\ ${ }^{1}$ Kazan State Agrarian University, Kazan 420015, Russia \\ ${ }^{2}$ Kazan Federal University, Kazan 420008, Russia
}

\begin{abstract}
The relevance of the issue is due to the need to improve the efficiency of the agro-industrial complex by uniting enterprises engaging in production, processing and sale of agricultural products. The aim is to develop recommendations on integration processes in the agricultural sector in order to improve the efficiency of the agricultural sector. The article discusses the objective nature of integration processes in modern agribusiness, identifies assumptions for creating integrated enterprises, such as unstable financial situations, worn-out material and technical resources, irrational organization of production, a low level of management and labor economics. The article describes a positive example of integrated formations in the Republic of Tatarstan, positive results of the activities of agro-industrial formations, which include the use of abandoned land and agricultural facilities, modernization of production using new equipment and technologies, increasing the attractiveness of agricultural labor, employment rate and incomes of the rural population, reduction of transaction costs in the agro-industrial chain, development of the agro-holding model as an effective interaction of enterprises of different agricultural sectors.
\end{abstract}

\section{Introduction}

Reforms in agriculture contributed to the transition from the planned principles of state regulation to the new principles of self-regulation in the market conditions. The results of the transition were very unsuccessful; measures taken led to a decrease in the main production and technological parameters in the agricultural sectors, such as sown areas, livestock, milk and meat production, etc.

The consequences turned into more significant destructive socio-economic phenomena like mass bankruptcy of agricultural enterprises, a decrease in the level and quality of life of the rural population. The old integrated agricultural units, integrators-industrial enterprises not related to agriculture ceased to exist due to the fact that integrators abandoned their assets in the agricultural sector, considering them inefficient $[1,2]$.

The crisis of agricultural enterprises was strengthened by the macroeconomic situation and a set of factors caused by the inability of managing the agrarian economy. The disintegration of the organizational and economic mechanism of relations between agribusiness partners, the structural imbalance between the sectors of agriculture and a number of other negative trends deteriorated the financial stability of agricultural and processing enterprises.

With the reduction of government support to agricultural enterprises, the problem of technological and economic disintegration of agricultural, processing, service, and trade enterprises has become more acute [3, 4]. Thus, there was a situation of a deep economic crisis in the agro-industrial complex, in which agricultural, processing and serving enterprises were not able to function. There was an urgent need to search for effective measures, eliminate the above-mentioned negative trends and problems, establish effective activities of enterprises in the agricultural production and processing sectors.

One of the main directions of transition to sustainable development of the agrarian sector was the use of organizational and economic potential of agro-industrial integration, which is based on the combination of organizational, technological, economic and information mechanisms [5-7].

At present, integration is the most important basis for the structuring of the economy, ensuring the interaction of business entities. At the same time, the potential of integration processes in the agricultural sector is not fully realized, since it does not include the most important objective element - intersectoral production cooperation.

\section{Materials and Methods}

The general methodological basis of the study is a system analysis. The vast material necessitated the use of various approaches, methods and techniques for the study of socio-economic processes, such as constructive, deterministic, retrospective, dynamic, and statistical.

The following methods were used to reveal the trends in the development of the food policy and their features: monographic, abstract-logical, computationalconstructive, economic-statistical, analogies. 
As the information and factual basis of the study, we used official data of the Federal State Statistics Service of the Russian Federation, the Ministry of Agriculture of the Russian Federation, the Ministry of Agriculture and Food of the Republic of Tatarstan, planning and reporting documents of agricultural organizations, monographs, dissertations, reports of research institutes, conference proceedings, expert evaluations, data obtained during the author's analysis and calculations.

\section{Results}

The emergence and development of agro-industrial enterprises and associations is the most important objective element in the process of formation of the agro-industrial complex in the Russian economy. The basis of this process is the deepening of social division of labor, which requires the development of intersectoral production cooperation.

The industrial-territorial agro-industrial complex represents the organic unity of technically, technologically and economically interconnected 1 agricultural enterprises processing agricultural raw materials, providing technical and transport services, producing production equipment, etc. It is an active process of deepening specialization, increasing concentration and intensification, cooperating and combining production of agricultural raw materials and industrial products.

The complexes themselves are not single units. The agrarian-industrial complexes formed at the previous stages were not industrial. Agricultural production was not transferred to the base of large-scale machine production. Farms were not specialized. There was no direct relationship between the participants $[8,9]$. As a result, many agro-industrial complexes were unstable, not effective.

Only with the achievement of a certain level of development of economic sectors, the combination of agriculture and industry can create an objective opportunity and need for the consistent implementation of tasks of integrating industries and enterprises. Thus, only at a certain stage of development of agro-industrial complexes does it become possible to create inter-branch enterprises and associations.

At the end of the 1990s, the trend towards agricultural enlargement through the formation of agricultural holdings intensified. Vertically integrated structures (agricultural holdings) increased the volume of agricultural production, make it possible to restructure financial, industrial and technological foundations of enterprises in various industries.

The unstable financial situation, the worn-out material and technical base, the irrational organization of production, the low level of management and the labor economy did not allow the enterprises to perform their own production and financial activities and forced them to look for ways out of the crisis by creating integrated agro-industrial formations.

The impasse was complicated by the absence of a possibility of obtaining investment funds from regional and federal budgets and credit organizations. Due to the low level of production, volumes and quality of products, sale problems arose. The integrator, possessing financial resources, invests in the creation of an agricultural holding and creates the technical and technological foundations for the development of agricultural production on a new platform. At the final stage, agricultural holdings contribute to the regular investment in villages, modern equipment, technologies $[10,11]$.

One of the examples of successful activities of integrated agro-industrial groups in the Republic of Tatarstan is the company "Red East Agro" created in 2003. "Red East Agro" was created by combining 64 agricultural organizations located in 6 districts of the Republic of Tatarstan: Zelenodolsky, Verkhneuslonsky, Alkeevsky, Alekseevsky, Nurlatsky and Spassky. This territory includes 136 settlements, with a population of more than 56,000 inhabitants. The main goal of business organization was to create a highly efficient industrial holding with a closed cycle "production-processingsales".

The first development stage falls on 2003-2009. This stage can be described as the formation period: creation of organizational and management structures, investment in the construction of mega-farms, purchase of material and technical equipment, highly productive breeding cattle from the Netherlands, Germany, the USA, Canada, Hungary, Denmark.

During this period, the agricultural holding achieved high production and economic indicators. The agricultural holding began to purchase high-performance equipment, build grain storages, feed mills and seed plants, milk processing plants, mega-farms with a capacity of 5.5-7.5 thousand livestock. Existing livestock keeping facilities are being reconstructed. In the past two years, 646.1 million rubles were spent, including: 394.7 million rubles - on the reconstruction of dairy farms, 111.7 million rubles - dairy equipment, 95.7 million rubles -on roads to the farms, 44 million rubles roads inside the farms.

The second stage (from 2010 till present) is a period of development of the company, vertical integration. Livestock breeding enterprises form a single complex that combines all business processes along the entire technological chain of milk production. Trained personnel, implementation of highly efficient technologies, a lean production system, provision of livestock with high-quality feed, high sanitary-hygienic and veterinary requirements contribute to the achievement of the company's goals.

To increase the volume of milk production, equipment and processes were modernized, feed production technologies were improved, and the staff was trained. Significant amounts of financial resources have been invested in the development of dairy production, modernization of large mega-farms, improvement of technology and quality of products. Great attention is paid to the feeding of livestock. Specialists are studying possibilities of reducing the feed costs and developing new diets. Much attention is paid to the replacement of purchased feed with own feed. 
To reduce the cost of substitutes for whole milk, the own line of production has been launched. The company has implemented new agricultural production technologies. By 2020, the agricultural holding will include 13 modern mega-farms with a capacity of 2 to 7 thousand animals. The main consumers of products are large milk processing enterprises of Russia. Today, the main area is production of high quality raw milk. The company is going to build the largest cattle breeding complex and sell pedigree cattle.

In 2016-2018, the reconstruction of 24 old fattening farms was completed. Now they are used as dairy farms. Currently, the agricultural holding has stabilized its production and economic parameters. The table shows the dynamics of the number of animals and volumes of produced and sold products over the past five.

Table 1. The dynamics of production indicators of PJSC "Red East Agro" for 2015-2019

\begin{tabular}{|l|c|c|c|c|c|}
\hline \multirow{2}{*}{ Indicator } & \multicolumn{5}{c|}{ Years } \\
\cline { 2 - 6 } & 2015 & 2016 & 2017 & 2018 & 2019 \\
\hline Livestock - total goal & 29697 & 28749 & 29984 & 29515 & 27541 \\
\hline including: milk cows & 19285 & 19314 & 19618 & 19628 & 19710 \\
\hline Young livestock & 10072 & 9159 & 10176 & 9727 & 7666 \\
\hline bulls & 340 & 276 & 190 & 160 & 165 \\
\hline Milk production, c & 903136 & 925143 & 947075 & 966518 & 995513 \\
\hline Milk sale, c c & 900001 & 864926 & 884762 & 900794 & 920849 \\
\hline Marketability, \% & 99.6 & 93.5 & 93.4 & 93.1 & 92.4 \\
\hline
\end{tabular}

Intensification of production allowed us to optimize the extensive parameters of production. Taking into account the situation in the dairy products market, while maintaining the number of cows, they gradually increased the volume of milk production.

The total number of cows was reduced due to fattening young cattle, switching to the rearing of young dairy stock. If in 2010 the total number of livestock was
32 thousand, by 2015 it decreased by $19 \%$; by 2019 , the total number of livestock was 27.5 thousand. An analysis of the financial situation of the agricultural holding showed that the financial condition is stable, the enterprise manages to maintain a positive balance of income and expenses, although the level of profitability is $1 \%$. A significant part of the funds is spent on interest payment (Table 2)

Table 2. Financial results of production and economic activities of PJSC "Red East Agro" for 2017-2018.

\begin{tabular}{|c|c|c|c|c|c|}
\hline \multirow{2}{*}{ Parameter } & \multicolumn{2}{|c|}{2018} & \multicolumn{2}{|l|}{2017} & \multirow{2}{*}{$\begin{array}{c}2018 \text { in } \\
\% \text { to } \\
2017\end{array}$} \\
\hline & $\begin{array}{l}\text { Absolutely, } \\
\text { thousand rubles }\end{array}$ & $\begin{array}{l}\text { In } \% \text { to } \\
\text { revenue }\end{array}$ & $\begin{array}{l}\text { Absolutely, } \\
\text { thousand rubles }\end{array}$ & $\begin{array}{l}\text { In } \% \text { to } \\
\text { revenue }\end{array}$ & \\
\hline Revenue & 3132244 & 100 & 3258834 & 100 & -4 \\
\hline Production cost & -3103855 & -99 & -3240307 & -99 & -4 \\
\hline Profit (loss) from sales & 28389 & 0.91 & 18527 & 1 & 53 \\
\hline Other income and expenses & 278124 & 9 & 487918 & 15 & -43 \\
\hline $\begin{array}{l}\text { Profit before interest, taxes and depreciation } \\
\text { (EBITDA) }\end{array}$ & 564172 & 18 & 766579 & 24 & -26 \\
\hline Profit before interest payment, taxation (EBITD) & 306520 & 10 & 506505 & 16 & -39 \\
\hline Interest & 282030 & 9 & 484465 & 15 & -42 \\
\hline Interest expense coverage ratio (EBIT) & 1.09 & 0 & 1.05 & 0 & 4 \\
\hline Profit (loss) before taxation & 24490 & 1 & 22040 & 1 & 11 \\
\hline Current income tax & -163 & 0 & -273 & 0 & -40 \\
\hline Net income (loss) & 24327 & 1 & 21767 & 1 & 12 \\
\hline
\end{tabular}

Table 3. The structure of income and expenses by activities of PJSC "Red East Agro", thousand rubles

\begin{tabular}{|c|c|c|c|c|}
\hline Activity & $\begin{array}{c}\text { Revenue excluding } \\
\text { VAT } 2018 \\
\end{array}$ & Cost 2018 & Profit & $\begin{array}{c}\text { share of } \\
\text { proceeds, } \%\end{array}$ \\
\hline Primary occupation & 2678817 & 2651924 & 26893 & 86 \\
\hline of which: milk sales & 1736675 & 1264516 & 472159 & 55 \\
\hline Sale of livestock & 916137 & 1367484 & -451347 & 29 \\
\hline Sale of other products & 26005 & 19924 & 6081 & 1 \\
\hline Other activities & 453427 & 451931 & 1496 & 14 \\
\hline of which: sale of goods and materials, services & 157622 & 157580 & 42 & 5 \\
\hline Other products & 295805 & 294351 & 1454 & 9 \\
\hline Total & 3132244 & 3103855 & 28389 & 100 \\
\hline
\end{tabular}

The structure of incomes and expenses (Table 3) shows that the main agricultural activity brings $86 \%$ of profit, of which dairy cattle breeding takes $55 \%$, the sales of cattle meat - $29 \%$. Accordingly, the bulk of profit is created by dairy farming and profitability of this industry is high and amounts to $37 \%$. Fattening of young cattle and sale of beef, as a traditionally unprofitable industry for the Republic of Tatarstan, brings significant losses with a loss ratio of $33 \%$, which reduces the level of profitability to $1 \%$ and reduces the 
investment level. In this regard, the agricultural holding began to raise highly productive animals. For this purpose, five breeding enterprises have been created; they are located in four districts of the Republic of Tatarstan and unite 59 livestock farms.

The enterprise takes an active part in creating social infrastructure for settlements, organizing social events, helping the poor, organizing national and national holidays. According to the results of the previous five years, 192 million rubles were spent on social events. Currently, 120 two-story private houses for young families and specialists working in the agricultural holding have been built in rural areas.

As a result, over the period of implementation of the investment project (2003-2019), the number of animals increased four times, the meat production volume - three times, the milk production volume - 4.9 times; annually, the company has 85 calves per 100 cows. Grain production increased 5 times, feed production increased 11.5 times, the yield of feed units from 1 ha of arable land increased 3.85 times. Today, Red East Agro is the leading dairy industry in the Republic of Tatarstan, it ranks 6th in the "Top 50 Raw Milk Manufacturing Companies" of Russia [12, 13].

\section{Conclusion}

The agro-industrial integration is an objective process that combines production, processing and trade enterprises into a single business process, increasing the competitiveness and quality of food products and expanding domestic and foreign sales markets, strengthening and stabilizing the financial condition of integrated enterprises, getting rid of unscrupulous intermediaries and local monopoly, eliminating speculative actions of trade and intermediary structures.

The positive results of the activities of agro-industrial enterprises are the involvement of abandoned lands and agricultural premises in the circulation, modernization of production based on new equipment and technologies; increasing the attractiveness of agricultural labor, employment rate and incomes of the rural population; reduction in transaction costs in the agro-industrial chain due to the centralized management of integrated entities uniting agricultural producers, processors and product dealers.

In this regard, agrarian policy, activities of enterprises should be aimed at overcoming negative trends in the development of integration processes based on the formation of developed food markets, effective sustainable agro-industrial production.

\section{References}

1. A.V. Petrikov, Economic and social problems of the modern stage of development of the agri-food system of Russia, Sci. works of the Free Econ. Society of Russ., 4, 219-226 (2019)

2. N.I. Shagayda, Agrarian structure as a factor in the sustainability of agriculture, Central Russ. Bull. of Soc. Sci., 12(5), 23-33 (2017)

3. N.I. Shagayda, Institutional restructuring of agriculture has occurred: where to go next? Peasant stud., 4(1), 173-178 (2019)

4. F.N. Mukhametgaliev, L.F. Sitdikova, F.F. Mukhametgalieva et al., Trends in the formation of the current agrifood policy of Russia, Stud. on Russ. Econ. Developm., 30(2), 162-165 (2019)

5. L.F. Sitdikova, Financial support for the sustainable development of agriculture, Bull. of the Samara State Univer. of Econ., 3(149), 71-76 (2017)

6. I.G. Gajnutdinov, N.F. Kashapov, M.M. Nafikov, A.R. Nigmatzyanov, The state of the technical level of domestic agricultural machinery, IOP Conf. Ser. Mater. Sci. and Engineer., 012047 (2019)

7. V.K. Giraev, N.I. Magomedova, L.A. Gadzhimuradova, Investment processes in the Russian Federation and regional imbalances in financial support, Finan. Econ., 4, 124-132 (2020)

8. Sh.M. Gazetdinov, M.Kh. Gazetdinov, O.S. Semicheva et al., Reserves for improving the efficiency of integrated formations, in: Int. Sci.Pract. Conf. Agricult. and Food Security: Technol., Innovat., Markets, Human Res. (Kazan, Russia, 13-14 November 2019) Retrieved from: https://doi.org/10.1051/bioconf/20201700026

9. A.R. Battalova, F.N. Mukhametgaliev, F.F. Mukhametgalieva, L.F. Sitdikova, Issues on increasing efficiency of agricultural business in the Republic of Tatarstan, J. of Environ. Treatment Techniques, 7 (Spec. iss.), 930-934 (2019)

10. D.I. Fayzrakhmanov, R.R. Shaidullin, G.S. Sharafutdinov et al., Innovative technologies in dairy cattle breeding of the Republic of Tatarstan, Bull. of Kazan State Agrar. Univer., 4, 34 (2006)

11. D.I. Fayzrakhmanov, M.G. Nurtdinov, G.S. Sharafutdinov et al., Organization of dairy cattle breeding based on technological innovations, Int. J. of Experim. Ed., 2, 52-54 (2012)

12. Monitoring the economic situation in Russia: trends and challenges of socio-economic development, 9(92), 20 (2019) Retrieved from: http://www.iep.ru/fles/ text / crisis_monitoring / 2019_9-92_June.pdf

13. Sectoral strategy of investment development of the Republic of Tatarstan for the period 2017-2021 with a perspective until 2030 (AIR of RT, Kazan, 2016) $15 \mathrm{p}$. 